\title{
PENGARUH BIAYA OPERASIONAL PENDIDIKAN TERHADAP OUTPUT PENDIDIKAN GURU SMK SE-KABUPATEN GRESIK DENGAN PRODUKTIVITAS KERJA SEBAGAI VARIABEL MODERASI
}

\author{
Rohmawati, SMP Muhammadiyah 12 GKB Gresik \\ rahma_ndukun@yahoo.com
}

\begin{abstract}
ABSTRAK
Penelitian ini bertujuan untuk (1) menganalisis pengaruh biaya operasional pendidikan terhadap output pendidikan di SMK se-kabupaten Gresik, (2) menganalisis pengaruh biaya operasional pendidikan terhadap output pendidikan dengan produktivitas kerja guru sebagai variabel moderasi di SMK se-kabupaten Gresik. Penelitian ini merupakan jenis penelitian explanatory dengan pendekatan kuantitatif. Populasi dalam penelitian ini adalah Sekolah Menengah Kejuruan (SMK) se-kabupaten Gresik. Teknik pengambilan sampel yang digunakan adalah purposive sampling. Adapun teknik pengumpulan data yang digunakan adalah teknik dokumentasi dan wawancara. Sedangkan metode analisis yang digunakan adalah teknik analisis statistik deskriptif, teknik analisis statistik infrensial regresi berganda dengan SPSS. Hasil penelitian menunjukkan bahwa Biaya Operasional Pendidikan tidak berpengaruh terhadap output pendidikan di SMK se-kabupaten Gresik dan Biaya Operasional Pendidikan tidak berpengaruh terhadap output pendidikan dengan produktivitas kerja guru sebagai variabel moderasi. Produktivitas kerja guru merupakan variabel yang kurang dapat digunakan sebagai variabel moderator atau tidak dapat digunakan sebagai variabel independen yang memiliki pengaruh terhadap variabel output pendidikan.
\end{abstract}

Kata Kunci: Biaya Operasional Pendidikan, Produktivitas Kerja Guru, Output Pendidikan.

\begin{abstract}
This study aims to (1) analyze the influence of education operational costs on educational output at Vocational High School/ SMK in Gresik regency, (2) analyze the effect of education operational costs on educational output with teacher's work productivity as a moderating variable at SMK in Gresik regency. This research is an explanatory research with a quantitative approach. The population in this research are vocational high schools (SMK) at Gresik regency. The sampling technique used was purposive sampling. The data collection techniques which used are documentation and interview techniques. While the method of analysis that used is descriptive statistical analysis techniques, statistical analysis techniques infrensial regression with SPSS. The results showed that the education operational cost does not affect the output of education at SMK in Gresik and education operational cost does not affect the educational output with teacher's work productivity as moderating variable. Teacher's
\end{abstract}


work productivity less can be used as a moderator variable or can not be used as independent variables that have an influence on educational output variables.

Keywords: Operational Cost of Education, Teacher's Work Productivity, Output Education.

\section{PENDAHULUAN}

Sekolah Menengah Kejuruan (SMK) sebagai bentuk satuan pendidikan kejuruan sebagaimana ditegaskan dalam penjelasan pasal 15 UU no. 20 tahun 2003 tentang sistem pendidikan nasional, merupakan pendidikan menengah yang mempersiapkan peserta didik untuk bekerja dalam bidang tertentu. Kegiatan pendidikan yang dijalankan oleh sekolah termasuk juga SMK harus berdasarkan pada tujuan pendidikan yang ingin dicapai. Pencapaian tujuan pendidikan salah satunya dapat dilihat dari hasil belajar atau output pendidikan.

Output pada dasarnya akan banyak dipengaruhi oleh input dan proses, keefektifan proses. Sistem input yang berkualitas tentu dapat menghasilkan output yang berkualitas pula. Soejoto (2007) menjelaskan bahwa "keluaran satuan pendidikan dapat berbentuk kognitif, afektif, dan psikomotor". Kognitif diartikan sebagai kemampuan yang dimiliki pebelajar dalam bentuk tingkat pengetahuan yang dimilikinya, sedangkan afektif atau non kognitif berarti sikap yang berhubungan dengan diri pebelajar. Psikomotor berhubungan dengan keterampilan yang dimiliki. Abidin (2013) juga menjelaskan dalam makalahnya bahwa output merupakan hasil dari proses, menghasilkan lulusan sesuai dengan standar tertentu dan tentunya diharapkan memenuhi keinginan masyarakat, orang tua dan pemerintah.

Menurut Supriadi (dalam Syamsuddin, 2009) menyatakan bahwa biaya pendidikan merupakan salah satu komponen masukan (input) yang sangat penting dalam penyelenggaraan pendidikan. Biaya pendidikan diperlukan untuk menfasilitasi pelaksanaan dan program sekolah (intra dan ekstra), dan dapat mengembangkan sekolah sebagai lembaga pendidikan yang memiliki output pendidikan yang berkualitas. Hal tersebut sesuai dengan hasil penelitian yang dilakukan oleh Sanjiwani (2012), bahwa biaya pendidikan memiliki korelasi yang signifikan dengan kualitas proses pembelajaran dan aspirasi pendidikan.

Menurut B.Bloom (dalam Budiningsing, 2005:74) mengatakan bahwa ada dua faktor utama yang dominan terhadap hasil belajar siswa/output siswa yaitu kerakteristik siswa yang meliputi (kemampuan, minat, hasil belajar sebelumnya, motivasi) dan karakter pengajaran yang meliputi (guru dan fasilitas belajar). Dalam mewujudkan hal tersebut tentunya membutuhkan biaya yang harus dikeluarkan oleh sekolah atau dikatakan sebagai biaya operasional sekolah/biaya operasional pendidikan. Penelitian yang dilakukan oleh Ekasari (2013) menyebutkan bahwa pengaruh biaya pendidikan dan kinerja guru terhadap prestasi belajar SMA Negeri di kabupaten Purwokerto masing-masing memiliki rata-rata sedang, artinya bahwa biaya pendidikan memiliki pengaruh terhadap prestasi belajar

Pemerintah pusat maupun daerah terus meningkatkan anggaran pendidikan untuk meningkatkan kualitas pendidikan. Hal tersebut sesuai 
dengan undang-undang Republik Indonesia nomor 20 tahun 2003 pasal 49 ayat (1) tentang Sistem Pendidikan Nasional bahwasanya dana pendidikan selain gaji pendidik dan biaya pendidikan kedinasan dialokasikan minimal $20 \%$ dari Anggaran Pendapatan dan Belanja Negara (APBN) pada sektor pendidikan dan minimal 20\% dari Anggaran Pendapatan dan Belanja Daerah (APBD).

Menurut peraturan Daerah kabupaten Gresik (Perda Gresik) No. 18 tahun 2006 tentang Sistem Penyelenggaraan Pendidikan pasal 23 menyebutkan bahwa pembiayaan pendidikan meliputi: biaya investasi, biaya operasional, dan biaya personal. Dalam pasal tersebut dijelaskan bahwa biaya operasional pendidikan meliputi: gaji pokok pendidik dan tenaga kependidikan dan tunjangan yang melekat pada gaji, bahan atau peralatan pendidikan habis pakai, dan biaya operasional pendidikan tak langsung berupa daya listrik, telepon, pemeliharaan sarana dan prasarana, uang lembur, transportasi, konsumsi, pajak, dan asuransi. Peraturan Mendiknas nomor 69 tahun 2009 juga menjelaskan bahwa, standar biaya operasi nonpersonalia adalah standar biaya yang diperlukan untuk membiayai kegiatan operasi nonpersonalia selama 1 (satu) tahun sebagai bagian dari keseluruhan dana pendidikan agar satuan pendidikan dapat melakukan kegiatan pendidikan secara teratur dan berkelanjutan sesuai Standar Nasional Pendidikan. Biaya operasi nonpersonalia meliputi biaya alat tulis sekolah (ATS), biaya bahan dan alat habis pakai (BAHP), biaya pemeliharaan dan perbaikan ringan, biaya daya dan jasa, biaya transportasi/perjalanan dinas, biaya konsumsi, biaya asuransi, biaya pembinaan siswa/ekstrakurikuler, biaya uji kompetensi, biaya praktik kerja industry (untuk SMK), dan biaya pelaporan. Setiap SMK memiliki besaran yang berbeda terhadap biaya-biaya tersebut di atas, hal itu sesuai dengan pencapaian tujuan pendidikan yang ditentukan oleh pelaksana sekolah untuk mewujudkan output pendidikan yang berkualitas.

Biaya operasional pendidikan yang dikeluarkan oleh pemerintah dari Anggaran Pendapatan dan Belanja Negara Untuk SMK di kabupaten Gresik sebesar Rp. 1.000.000,- per siswa per tahun. Sedangkan yang berasal dari Anggaran Pendapatan dan Belanja Daerah sebesar Rp. 20.000,- per siswa per bulan. Biaya operasional pendidikan yang dikeluarkan oleh pemerintah tersebut dikelola secara mandiri oleh sekolah masing-masing. Sekolah swasta memiliki kebijakan masing-masing dalam menentukan biaya operasional masing-masing sekolahnya. Upaya pemerintah maupun swasta yang terus meningkatkan biaya operasional pendidikan setiap tahunnya dimaksudkan untuk membantu sekolah dalam meningkatkan output pendidikan di setiap tahunnya.

Flower (1998) dalam penelitiannya menjelaskan bahwa orang tua mahasiswa berani mengeluarkan biaya pendidikan yang tinggi bukan untuk memperoleh kualitas pendidikan yang rendah, akan tetapi mereka menginginkan kualitas pendidikan yang tinggi. Kualitas pendidikan yang tinggi bermula dari para pengajar yang memiliki kualifikasi sesuai dengan pelajaran yang mereka ampuh, sedangkan untuk mewujudkan hal tersebut tentunya membutuhkan biaya yang tinggi. Meskipun penelitian yang dilakukan oleh Elberts dkk. (1999) di Amerika Serikat menyatakan bahwa membayar jasa tidak berpengaruh pada indeks prestasi rata-rata, berkurangnya persentase siswa yang putus kuliah, berkurangnya rata-rata kehadiran setiap hari, dan 
meningkatnya persentase siswa yang gagal. Akan tetapi penggunaan biaya pendidikan yang efektif dan efisien dapat mempermudah jalannya kegiatan pembelajaran di sekolah terutama mendukung guru dalam melaksankan kegiatan belajar mengajar. Dengan demikian diharapkan mampu meningkatkan output siswa. Kualitas pembelajaran yang baik akan berpengaruh terhadap kualitas hasil belajar (output).

Berdasarkan pemikiran tersebut di atas, indikator output pendidikan dalam penelitian ini dapat dilihat dari hasil NEM ujian nasional (UN). Ujian nasional atau disingkat UN/UNAS adalah sistem evaluasi standar pendidikan dasar dan menengah secara nasional dan persamaan mutu tingkat pendidikan antar daerah yang dilakukan oleh pusat penilaian pendidikan, Depdiknas di Indonesia berdasarkan Undang-Undang Republik Indonesia no. 20 tahun 2003 menyatakan bahwa dalam rangka pengendalian mutu pendidikan secara nasional dilakuan evaluasi sebagai bentuk akuntabilitas penyelenggara pendidikan kepada pihak-pihak yang berkepentingan. Peraturan Pemerintah (PP) pasal 3 No. 1 tahun 2005 menyebutkan bahwa tujuan diselenggarakannya Ujian Nasional (UN) adalah untuk mengukur dan menilai kompetensi ilmu pengetahuan dan teknologi peserta didik.

Kondisi mutu output pendidikan SMK Kabupaten Gresik antara lain dapat dilihat dari rata-rata NEM Ujian Nasional yang diperoleh pada tahun pelajaran 2010/2011, 2011/2012, 2012/2013, 2013/2014. Rata-rata NEM Ujian Nasional mengalami fluktuatif dan rata-rata turun $1.97 \%$ selama 4 tahun. Kondisi umum mutu output pendidikan SMK kabupaten Gresik dapat dilihat dari tabel rata-rata NEM UN SMK se kabupaten Gresik sebagai berikut:

Tabel 1. Rata-rata NEM UN SMK Se-Kab Gresik

\begin{tabular}{|c|c|c|}
\hline NO & Tahun Pelajaran & Rata-rata NEM \\
\hline 1 & $2010 / 2011$ & 34.40 \\
\hline 2 & $2011 / 2012$ & 34.69 \\
\hline 3 & $2012 / 2013$ & 30.94 \\
\hline 4 & $2013 / 2014$ & 28.50 \\
\hline
\end{tabular}

Sumber : Dinas Pendidikan Kabupaten Gresik (2015)

Mallet dkk. (2009) menjelaskan bahwa, untuk memaksimalkan output siswa yaitu dengan mengoptimalkan guru sebagai input dalam satuan pendidikan (sekolah). Output siswa yang maksimal dapat tercapai apabila; 1) guru memiliki waktu yang cukup untuk bekerja sama dengan teman sejawat sehingga dapat saling bertukar pikiran dan mengeluarkan ide-ide baru. 2) guru mampu menggunakan waktu dengan efektif. 3) guru memaksimalkan waktunya untuk mencari inovasi baru dalam pembelajaran, sehingga siswa memiliki kesempatan untuk mengembangkan ide-ide mereka sendiri. 4) guru memiliki hasil pengamatan dari teman sejawat, Empat hal yang mempengaruhi maksimalnya output siswa tersebut adalah bagian dari produktivitas kerja guru, sedangkan produktifitas kerja guru yang tinggi diharapkan akan meningkatkan mutu output pendidikan. Penelitian tentang produktivitas guru juga pernah dilakukan oleh Jackson (2010). Jackson menjelaskan bahwa produktivitas kerja 
guru sangat dipengaruhi oleh gaji guru dan peningkatan produktivitas guru berakibat pada peningkatan prestasi belajar siswa. sedangkan gaji guru adalah bagian dari unsur biaya operasional pendidikan.

Secara umum yang dimaksud dengan produktivitas kerja adalah perbandingan antara hasil yang dicapai (output) dengan keseluruhan sumber daya yang digunakan (input). Fare et al. (2006) mengungkapkan bahwa pertumbuhan produktivitas dalam pendidikan akan mengalami perubahan ketika kuantitas dari input juga mengalami perubahan, seperti pertumbuhan jumlah guru, dan sarana pendidikan, sedangkan pertambahan jumlah guru dan sarana pendidikan akan menyebabkan bertambah pula biaya pendidikan yang dikeluarkan oleh sekolah. Menurut Sutikno (2009) pengukuran produktivitas pendidikan dapat dilakukan dengan tiga cara : (1) dimensi keluaran administrasi, (2) dimensi keluaran perubahan perilaku, (3) dimensi keluaran ekonomi. Pengukuran dari dimensi keluaran administrasi maksudnya adalah dengan melihat seberapa baik pelayanan yang dapat diberikan oleh guru, kepala sekolah maupun pihak lain yang berkepentingan. Adapun dimensi keluaran yang kedua menurut Sutikno (2009) yaitu dimensi perubahan perilaku. Pada dimensi keluaran perubahan perilaku, produktifitas guru dapat dilihat dari nilai-nilai yang diperoleh peserta didik sebagai gambaran dari prestasi akademik yang telah dicapai. Hasil ujian nasional merupakan salah satu prestasi akademik yang diperoleh peserta didik sebagai efek dari produktivitas guru sebagaiman dalam undang-undang no. 20 tahun 2003, semakin banyak siswa yang lolos ujian nasional, maka semakin banyak output pendidikan yang dihasilkan oleh sekolah tersebut. Sedangkan pengukuran produktivitas yang ketiga menurut Sutikno (2009) yaitu dilihat dari dimensi keluaran ekonomi. Pengukuran dari dimensi keluaran ekonomis dilakukan dengan mengaitkan layanan pendidikan dengan aspek pembiayaan. Dari uraian tersebut diatas, dapat dikatakan bahwa produktivitas kerja guru adalah jumlah siswa yang lulus (output) dibanding dengan jumlah guru (input), sehingg dengan biaya yang maksimal diharapkan mampu menghasilkan output pendidikan yang maksimal melalui produktivitas kerja guru yang maksimal pula.

Sebagai gambaran, tenaga pendidik atau guru SMK baik negeri maupun swasta di kabupaten Gresik, berdasarkan data dari dinas pendidikan kabupaten Gresik sejak tahun pelajaran 2006-2007 sampai dengan tahun pelajaran 20132014 adalah sebanyak 1.399 guru. Jumlah guru mengalami kenaikan rata-rata sebesar $10.95 \%$ setiap tahunnya, sedangkan jumlah siswa SMK tahun pelajaran 2013-2014 adalah sebanyak 4.049 siswa. Jumlah siswa SMK di kabupaten Gresik sejak tahun pelajaran 2003-2004 sampai dengan 2013-2014 mengalami kenaikan rata-rata sebesar $9.52 \%$ setiap tahunnya. Akan tetapi kenaikan jumlah guru di setiap tahunnya lebih besar dari pada jumlah siswa.

\section{METODE PENELITIAN}

Jenis penelitian ini adalah explanatory (explanatory research) yaitu suatu penelitian untuk mencari dan menjelaskan hubungan kausal antar variabel (Sukmadinata, 2012), penelitian ini bertujuan untuk menguji secara empirik 
hubungan sebab akibat (kausalitas) antar beberapa variabel seperti gambar model berikut ini :

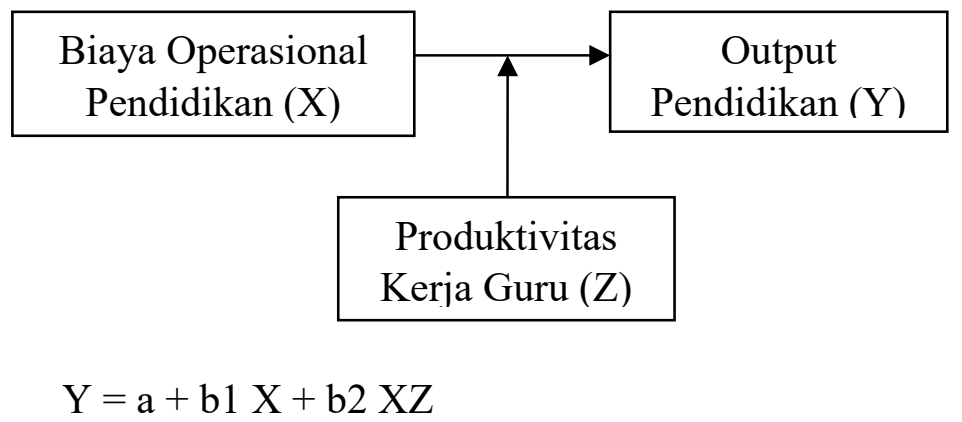

Populasi dalam penelitian ini adalah seluruh SMK di kabupaten Gresik, adapun teknik pengambilan sampel yang digunakan adalah Purposive Sampling (Sugiyono, 2008), yaitu teknik penentuan sampel dengan pertimbangan tertentu. Sekolah yang dijadikan sebagai sampel adalah sekolah dengan pertimbangan sudah memiliki lulusan minimal 10 tahun, yaitu SMK Negeri 1 Cerme, SMK Sunan Giri Menganti, SMK Muhammadiyah 1 Gresik, SMK As-Sa'adah, SMK Maskumambang 1, SMK Yasmu, SMK PGRI 1 Gresik, SMK Semen Gresik, SMK Karya Bhakti, SMK NU, SMK Dharma Wanita, dan SMK Taruna Jaya. Hal tersebut dikarenakan data yang dijadikan sebagai bahan penelitian adalah data biaya operasional pendidikan, produktivitas kerja guru, dan output pendidikan selama 10 tahun (2004-2005 s/d 2013-2014) di masing-masing sekolah dengan tujuan untuk meningkatkan kevalidan dari data tersebut. Data dalam penelitian ini adalah data sekunder dimana data tersebut sudah tersedia sehingga data tersebut diperoleh peneliti dengan metode dokumentasi, yaitu suatu cara memperoleh data atau informasi tentang hal-hal yang ada kaitannya dengan penelitian dengan jalan melihat kembali laporan tertulis yang lalu baik berupa angka maupun keterangan (Arikunto, 2006). Teknik analisis data yang digunakan dalam penelitian ini adalah teknik analisis statistik deskriptif dan analisis statistik infrensial regresi berganda dengan SPSS .

\section{HASIL PENELITIAN DAN PEMBAHASAN}

Indikator biaya operasional pendidikan dalam penelitian ini sesuai dengan undang-undang Republik Indonesia nomor 20 tahun 2003 pasal 49 ayat (1) tentang Sistem Pendidikan Nasional dan peraturan Daerah kabupaten Gresik (Perda Gresik) pasal 23 No. 18 tahun 2006 tentang Sistem Penyelenggaraan Pendidikan. Penelitian ini fokus pada sekolah yang sudah meluluskan minimal 10 kali, sehingga data yang diambil adalah mulai tahun pelajaran 2004-20005 s/d 2013-2014. Hasil observasi menyebutkan bahwa ada 12 SMK yang sudah meluluskan siswa lebih dari 10 tahun. Sedangkan output pendidikan pada penelitian ini dilihat dari nilai UN siswa sebagai salah satu output pendidikan. Selain itu hasil observasi juga menyebutkan bahwa ada 95\% lulusan SMK yang melanjutkan ke dunia kerja dan hanya 5\% yang melanjutkan pendidikan di perguruan tinggi baik swasta maupun negeri. 
Jumlah lulusan menunjukkan adanya tingkat produktivitas kerja guru terhadap jumlah guru yang ada.

Tenaga pendidik atau guru SMK baik negeri maupun swasta di kabupaten Gresik, berdasarkan data dari dinas pendidikan kabupaten Gresik sejak tahun pelajaran 2006-2007 sampai dengan tahun pelajaran 2013-2014 adalah sebanyak 1.399 guru. Jumlah guru mengalami kenaikan rata-rata sebesar $10.95 \%$ setiap tahunnya, sedangkan jumlah siswa SMK tahun pelajaran 2013-2014 adalah sebanyak 4.049 siswa. Jumlah siswa SMK di kabupaten Gresik sejak tahun pelajaran 2004-2005 sampai dengan 2013-2014 mengalami kenaikan rata-rata sebesar $9.52 \%$ setiap tahunnya. Hal tersebut menunjukkan bahwa kenaikan jumlah guru di setiap tahunnya lebih besar dari pada jumlah siswa. Kenaikan jumlah guru dan siswa mengakibatkan naiknya biaya operasional pendidikan yang seharusnya dapat mengakibatkan kenaikan output pendidikan.

Total biaya operasional yang dikeluarkan oleh masing-masing sekolah yang menjadi sampel dalam penelitian ini mulai tahun 2004-2005 s/d 20132014 dapat dilihat pada tabel dibawah ini:

Tabel 2. Total biaya operasional pendidikan tahun 2004-2005 s/d 2013-2014

\begin{tabular}{|c|l|lc|}
\hline NO & NAMA SEKOLAH & \multicolumn{2}{|c|}{ BOP } \\
\hline 1 & SMK Negeri 1 Cerme & Rp. 27.750 .525 .587 \\
\hline 2 & SMK Sunan Giri Menganti & Rp. & 4.194 .049 .500 \\
\hline 3 & SMK Muhammadiyah 1 Gresik & Rp. & 4.214 .300 .149 \\
\hline 4 & SMK Assa'adah & Rp. & 3.752 .155 .000 \\
\hline 5 & SMK Maskumambang 1 & Rp. & 5.695 .424 .802 \\
\hline 6 & SMK Yasmu & Rp. & 10.180 .231 .150 \\
\hline 7 & SMK PGRI 1 Gresik & Rp. & 18.626 .457 .103 \\
\hline 8 & SMK Semen Gresik & Rp. & 17.303 .705 .506 \\
\hline 9 & SMK Karya Bhakti & Rp. & 2.073 .682 .000 \\
\hline 10 & SMK NU Gresik & Rp. & 9.340 .449 .000 \\
\hline 11 & SMK Dharma Wanita & Rp. & 3.410 .419 .341 \\
\hline 12 & SMK Taruna Jaya & Rp. & 7.193 .140 .000 \\
\hline Rata-Rata BOP 2004-2005 s/d 2013-2014 & Rp. & $\mathbf{9 . 4 7 7 . 8 7 8 . 2 6 2}$ \\
\hline BOP Tertinggi (SMKN 1 Cerme) & Rp. & $\mathbf{2 7 . 7 5 0 . 5 2 5 . 5 8 7}$ \\
\hline BOP Terendah (SMK Karya Bhakti) & Rp. & $\mathbf{2 . 0 7 3 . 6 8 2 . 0 0 0}$ \\
\hline
\end{tabular}

Adapun perkembangan biaya operasional pendidikan sejak tahun 20042005 s/d 2013-2014 dapat dilihat pada tabel berikut ini : 
Tabel 3. Perkembangan biaya operasional pendidikan 2004-2005 s/d 2013-2014

\begin{tabular}{|c|c|c|c|c|c|c|c|c|c|c|c|}
\hline \multirow{2}{*}{$\begin{array}{l}\mathbf{N} \\
\mathbf{O}\end{array}$} & \multirow{2}{*}{ SEKOLAH } & \multicolumn{10}{|c|}{ TAHUN PELAJARAN (Per juta) } \\
\hline & & $\begin{array}{r}2004- \\
2005 \\
\end{array}$ & $\begin{array}{r}2005- \\
2006 \\
\end{array}$ & $\begin{array}{l}2006- \\
2007 \\
\end{array}$ & $\begin{array}{c}2007- \\
2008\end{array}$ & $\begin{array}{c}2008- \\
2009 \\
\end{array}$ & $\begin{array}{l}2009- \\
2010\end{array}$ & $\begin{array}{l}2010- \\
2011\end{array}$ & $\begin{array}{l}2011- \\
2012\end{array}$ & $\begin{array}{l}2012- \\
2013\end{array}$ & $\begin{array}{l}2013- \\
2014\end{array}$ \\
\hline 1 & SMKN 1 Cerme Gresik & 1,902 & 2,035 & 2,177 & 2,352 & 2,540 & 2,743 & 3,017 & 3,319 & 3,651 & 4,016 \\
\hline 2 & SMK Sunan Giri & 97 & 121 & 148 & 179 & 270 & 380 & 478 & 786 & 848 & 888 \\
\hline 3 & SMK Muh 1 Gresik & 261 & 294 & 296 & 315 & 318 & 385 & 461 & 525 & 554 & 804 \\
\hline 4 & SMK As-Sa'adah & 276 & 290 & 314 & 329 & 346 & 375 & 386 & 452 & 477 & 508 \\
\hline 5 & SMK Maskumambang 1 & 475 & 499 & 524 & 556 & 560 & 578 & 606 & 624 & 600 & 675 \\
\hline 6 & SMK Yasmu & 397 & 531 & 680 & 979 & 1,028 & 1,051 & 1,187 & 1,364 & 1,510 & 1,456 \\
\hline 7 & SMK PGRI 1 Gresik & 812 & 1,068 & 1,140 & 1,382 & 1,457 & 1,686 & 2,242 & 2,440 & 2,640 & 3,759 \\
\hline 8 & SMK Semen Gresik & 1,023 & 1,125 & 1,238 & 1,362 & 1,498 & 1,648 & 1,845 & 2,067 & 2,165 & 3,334 \\
\hline 9 & SMK Karya Bhakti & 118 & 137 & 155 & 174 & 195 & 215 & 235 & 255 & 277 & 313 \\
\hline 10 & SMK NU Gresik & 563 & 625 & 696 & 772 & 858 & 953 & 1,059 & 1,181 & 1,314 & 1,320 \\
\hline 11 & SMK Dharmawanita & 208 & 217 & 246 & 197 & 251 & 298 & 355 & 498 & 485 & 654 \\
\hline 12 & SMK Taruna Jaya & 538 & 566 & 616 & 648 & 689 & 741 & 780 & 830 & 874 & 910 \\
\hline \multicolumn{2}{|c|}{ Total } & 6,669 & 7,509 & 8,228 & 9,245 & 10,008 & 11,053 & 12,652 & 14,340 & 15,394 & 18,636 \\
\hline \multicolumn{2}{|c|}{ Rata-Rata } & 556 & 626 & 686 & 770 & 834 & 921 & 1,054 & 1,195 & 1,283 & 1,553 \\
\hline
\end{tabular}

Tabel 3 di atas menunjukkan bahwa SMK Negeri 1 Cerme adalah SMK yang memiliki biaya operasional pendidikan tertinggi berturut-turut selama 10 selama kurun waktu 10 tahun. Sedangkan total rata-rata biaya yang dikeluarkan oleh sekolah (SMK) dari tahun 2004-2005 s/d 2013-2014 sebesar Rp. 9.477.878.262,- dengan biaya operasional pendidikan tertinggi dikeluarkan oleh SMKN 1 Cerme Gresik sebesar Rp. 27.750.525.587,- , dan biaya operasional pendidikan terendah dikeluarkan oleh SMK Karya Bhakti Gresik dengan jumlah Rp. 2.073.682.000,-. Bidang keahlian yang dimiliki oleh SMKN 1 Cerme lebih banyak dari pada SMK Sunan Giri Gresik, yaitu ada 7 bidang keahlian sedangkan SMK Karya Bhakti Gresik memiliki 4 bidang keahlian.

Produktivitas kerja guru dalam penelitian ini dilihat dari jumlah lulusan dibanding dengan jumlah guru. Seperti yang diungkapkan oleh Coelli at al. (dalam Ahlgrim, 2010) menjelaskan bahwa produktivitas adalah hubungan antara input dan output dalam fungsi produksi. Guru sebagai bagian dari input pendidikan dan lulusan merupakan output dari pendidikan, dari rasio tersebut, maka dapat dilihat produktivitas kerja guru suatu satuan pendidikan dalam hal ini adalah SMK. Total produktivitas kerja guru SMK se-kabupaten Gresik dapat dilihat pada tabel di bawah ini : 
Tabel 4. Produktivitas kerja guru SMK tahun 2004-2005 s/d 20132014

\begin{tabular}{|c|l|c|}
\hline NO & NAMA SEKOLAH & $\begin{array}{c}\text { PRODUKTIVITAS } \\
\text { KERJA GURU }\end{array}$ \\
\hline 1 & SMK Negeri 1 Cerme & 3.68 \\
\hline 2 & SMK Sunan Giri Menganti & 3.56 \\
\hline 3 & SMK Muhammadiyah 1 Gresik & 3.41 \\
\hline 4 & SMK Assa'adah & 4.89 \\
\hline 5 & SMK Maskumambang 1 & 2.45 \\
\hline 6 & SMK Yasmu & 4.13 \\
\hline 7 & SMK PGRI 1 Gresik & 8.93 \\
\hline 8 & SMK Semen Gresik & 3.81 \\
\hline 9 & SMK Karya Bhakti & 2.08 \\
\hline 10 & SMK NU Gresik & 4.21 \\
\hline 11 & SMK Dharma Wanita & 2.65 \\
\hline 12 & SMK Taruna Jaya & 4.70 \\
\hline Rata-rata & $\mathbf{4 . 0 4}$ \\
\hline $\begin{array}{l}\text { Produktivitas tertinggi (SMK PGRI 1 } \\
\text { Gresik) }\end{array}$ & $\mathbf{8 . 9 3}$ \\
\hline $\begin{array}{l}\text { Produktivitas terendah (SMK Karya Bhakti } \\
\text { Gresik) }\end{array}$ & $\mathbf{2 . 0 8}$ \\
\hline
\end{tabular}

Adapun perkembangan produktivitas kerja guru SMK sejak tahun 20042005 s/d 2013-2014 dapat dilihat pada tabel berikut ini :

Tabel 5. Perkembangan produktivitas kerja guru SMK tahun 2004-2005 s/d 2013-2014

\begin{tabular}{|c|c|c|c|c|c|c|c|c|c|c|c|}
\hline \multirow[b]{2}{*}{ NO } & \multirow[b]{2}{*}{ SEKOLAH } & \multicolumn{10}{|c|}{ TAHUN PELAJARAN } \\
\hline & & $\begin{array}{l}\text { 2004- } \\
2005\end{array}$ & $\begin{array}{l}2005- \\
2006\end{array}$ & $\begin{array}{l}2006- \\
2007\end{array}$ & $\begin{array}{l}2007- \\
2008\end{array}$ & $\begin{array}{l}2008- \\
2009\end{array}$ & $\begin{array}{l}2009- \\
2010\end{array}$ & $\begin{array}{l}\text { 2010- } \\
2011\end{array}$ & $\begin{array}{l}2011- \\
2012\end{array}$ & $\begin{array}{l}2012- \\
2013\end{array}$ & $\begin{array}{l}2013 \\
2014\end{array}$ \\
\hline 1 & SMKN 1 Cerme Gresik & 3.13 & 3.30 & 3.53 & 3.81 & 3.98 & 4.00 & 3.96 & 3.82 & 3.61 & 3.62 \\
\hline 2 & SMK Sunan Giri & 1.96 & 1.82 & 2.55 & 2.17 & 1.83 & 2.92 & 3.47 & 5.30 & 6.77 & 6.78 \\
\hline 3 & SMK Muh 1 Gresik & 5.00 & 4.64 & 2.94 & 3.21 & 3.04 & 1.77 & 3.06 & 3.34 & 3.00 & 4.12 \\
\hline 4 & SMK As-Sa'adah & 4.89 & 4.95 & 6.13 & 5.71 & 5.58 & 5.20 & 4.80 & 3.98 & 4.39 & 3.31 \\
\hline 5 & SMK Maskumambang 1 & 1.70 & 1.95 & 1.83 & 1.74 & 1.44 & 2.83 & 3.53 & 3.82 & 2.82 & 2.79 \\
\hline 6 & SMK Yasmu & 3.18 & 4.11 & 3.89 & 4.48 & 3.90 & 4.78 & 5.19 & 4.70 & 3.88 & 3.15 \\
\hline 7 & SMK PGRI 1 Gresik & 9.24 & 9.86 & 9.63 & 9.60 & 8.31 & 9.17 & 8.42 & 8.65 & 8.62 & 7.83 \\
\hline 8 & SMK Semen Gresik & 4.27 & 4.42 & 3.69 & 3.93 & 4.27 & 3.64 & 3.82 & 3.32 & 3.58 & 3.12 \\
\hline 9 & SMK Karya Bhakti & 2.23 & 2.58 & 1.95 & 2.48 & 1.77 & 1.65 & 1.57 & 2.44 & 1.95 & 2.20 \\
\hline 10 & SMK NU Gresik & 4.16 & 3.79 & 5.05 & 4.23 & 4.15 & 4.56 & 3.86 & 3.86 & 4.94 & 3.54 \\
\hline 11 & SMK Dharmawanita & 1.57 & 2.27 & 2.77 & 2.10 & 1.95 & 2.58 & 3.08 & 3.10 & 2.94 & 4.16 \\
\hline 12 & SMK Taruna Jaya & 4.88 & 4.32 & 4.16 & 3.79 & 3.78 & 4.40 & 4.76 & 5.47 & 6.15 & 5.27 \\
\hline \multicolumn{2}{|c|}{ Total } & 46.19 & 43.69 & 43.95 & 43.44 & 40.23 & 43.09 & 44.77 & 46.35 & 46.50 & 44.62 \\
\hline \multicolumn{2}{|c|}{ Total Rata-rata } & 3.85 & 4.00 & 4.01 & 3.94 & 3.67 & 3.96 & 4.13 & 4.32 & 4.39 & 4.16 \\
\hline
\end{tabular}


Tabel 5 di atas menunjukkkan bahwa selama 10 tahun, setiap SMK memiliki produktivitas kerja guru yang fluktuatif, akan tetapi SMK PGRI 1 Gresik adalah sekolah yang memiliki tingkat produktivitas kerja yang tinggi selama 10 tahun berturut-turut. Berdasarkan data yang diperoleh peneliti, total rata-rata produktivitas kerja guru SMK se-kabupaten Gresik mulai tahun 20042005 s/d 2013-2014 adalah sebesar 4,04. Produktivitas kerja guru SMK sekabupaten Gresik tertinggi diperoleh SMK PGRI 1 sebesar 8,93, sedangkan produktivitas kerja guru SMK terendah se-kabupaten Gresik adalah SMK Karya Bhakti sebesar 2,08. Produktivitas kerja guru yang tinggi diharapkan dapat memberikan dampak yang positif terhadap output pendidikan masingmasing SMK.

Output pendidikan dalam penelitian ini adalah rata-rata nilai ujian nasional (NEM) siswa SMK di kabupaten Gresik mulai tahu 2004-2005 s/d 2013-2014. Berdasarkan data yang diperoleh, total output pendidikan SMK seKabupaten Gresik selama 10 tahun dapat dilihat pada tabel dan grafik di bawah ini :

Tabel 6. Rata-rata Nilai Ujian Nasional (NEM) SMK di kabupaten Gresik (Output Pendidikan). 2004-2005 s/d 2013-2014

\begin{tabular}{|l|l|c|}
\hline NO & \multicolumn{1}{|c|}{ NAMA SEKOLAH } & RATA-RATA NEM \\
\hline 1 & SMK Negeri 1 Cerme & 32.45 \\
\hline 2 & SMK Sunan Giri Menganti & 30.89 \\
\hline 3 & SMK Muhammadiyah 1 Gresik & 30.24 \\
\hline 4 & SMK Assa'adah & 32.51 \\
\hline 5 & SMK Maskumambang 1 & 27.27 \\
\hline 6 & SMK Yasmu & 28.67 \\
\hline 7 & SMK PGRI 1 Gresik & 30.33 \\
\hline 8 & SMK Semen Gresik & 31.77 \\
\hline 9 & SMK Karya Bhakti & 30.63 \\
\hline 10 & SMK NU Gresik & 31.87 \\
\hline 11 & SMK Dharma Wanita & 30.75 \\
\hline 12 & SMK Taruna Jaya & 30.26 \\
\hline Rata-Rata NEM di kabupaten Gresik & $\mathbf{3 0 . 6 4}$ \\
\hline Rata-rata NEM Tertinggi (As-Sa'adah) & $\mathbf{3 2 . 5 1}$ \\
\hline $\begin{array}{l}\text { Rata-rata NEM Terendah (SMK } \\
\text { Maskumambang) }\end{array}$ & $\mathbf{2 7 . 2 7}$ \\
\hline
\end{tabular}

Tabel 4 di atas menunjukkan bahwa, output pendidikan SMK sekabupaten Gresik mulai tahun 2004-2005 s/d 2013-2014 tergolong bagus. Hal itu dikarenakan, secara keseluruhan nilai-nilai tersebut berada di atas nilai minimal yang telah distandarkan oleh pemerintah sebagai nilai standar minimum kelulusan. Tabel tersebut menunjukkan bahwa sekolah menengah kejuruan (SMK) di kabupaten Gresik mampu menghasilkan output pendidikan yang baik, yaitu dengan nilai rata-rata 30.64. Output pendidikan tertinggi diperoleh SMK As-Sa'adah yaitu sebesar 32.51, dan output pendidikan terendah adalah SMK Maskumambang 1, yaitu dengan nilai 27.27. Adapun 
perkembangan output pendidikan SMK sekabupaten Gresik sejak tahun 20042005 s/d 2013-2014 dapat dilihat pada tabel berikut ini:

Tabel 7. Perkembangan Output Pendidikan SMK sejak tahun 2004-2005 s/d 2013-2014

\begin{tabular}{|c|c|c|c|c|c|c|c|c|c|c|c|}
\hline \multirow[b]{2}{*}{$\begin{array}{l}\mathbf{N} \\
\mathbf{O}\end{array}$} & \multirow[b]{2}{*}{ SEKOLAH } & \multicolumn{10}{|c|}{ TAHUN PELAJARAN } \\
\hline & & $\begin{array}{l}2004- \\
2005\end{array}$ & $\begin{array}{l}2005- \\
2006\end{array}$ & $\begin{array}{l}2006- \\
2007\end{array}$ & $\begin{array}{l}2007- \\
2008\end{array}$ & $\begin{array}{c}2008- \\
2009\end{array}$ & $\begin{array}{l}2009- \\
2010\end{array}$ & $\begin{array}{l}2010- \\
2011\end{array}$ & $\begin{array}{l}2011- \\
2012\end{array}$ & $\begin{array}{l}2012- \\
2013\end{array}$ & $\begin{array}{l}2013- \\
2014\end{array}$ \\
\hline 1 & $\begin{array}{l}\text { SMKN } 1 \\
\text { Cerme } \\
\text { Gresik } \\
\end{array}$ & 29.44 & 33.53 & 32.66 & 31.92 & 30.57 & 32.57 & 34.92 & 35.74 & 31.53 & 31.66 \\
\hline 2 & $\begin{array}{l}\text { SMK Sunan } \\
\text { Giri }\end{array}$ & 28.92 & 29.88 & 30.76 & 32.54 & 32.69 & 30.20 & 33.47 & 33.12 & 30.16 & 27.13 \\
\hline 3 & $\begin{array}{l}\text { SMK Muh } 1 \\
\text { Gresik }\end{array}$ & 26.32 & 31.26 & 30.15 & 30.41 & 31.52 & 34.35 & 32.40 & 32.80 & 30.79 & 22.41 \\
\hline 4 & $\begin{array}{l}\text { SMK As- } \\
\text { Sa'adah }\end{array}$ & 32.40 & 32.36 & 33.00 & 33.08 & 32.12 & 32.96 & 33.20 & 33.76 & 31.48 & 30.72 \\
\hline 5 & $\begin{array}{l}\text { SMK } \\
\text { Maskumamb } \\
\text { ang } 1 \\
\end{array}$ & 23.74 & 25.30 & 25.50 & 27.25 & 26.65 & 28.94 & 34.12 & 29.23 & 27.77 & 24.17 \\
\hline 6 & $\begin{array}{l}\text { SMK } \\
\text { Yasmu }\end{array}$ & 24.21 & 24.16 & 24.16 & 25.50 & 24.87 & 39.32 & 38.32 & 31.87 & 29.78 & 24.46 \\
\hline 7 & $\begin{array}{l}\text { SMK PGRI } \\
1 \text { Gresik }\end{array}$ & 24.20 & 28.68 & 32.24 & 33.04 & 35.28 & 30.96 & 31.44 & 31.68 & 29.84 & 25.92 \\
\hline 8 & $\begin{array}{l}\text { SMK Semen } \\
\text { Gresik }\end{array}$ & 31.65 & 32.35 & 33.44 & 32.35 & 32.60 & 30.82 & 32.80 & 31.01 & 28.20 & 32.45 \\
\hline 9 & $\begin{array}{l}\text { SMK Karya } \\
\text { Bhakti }\end{array}$ & 29.75 & 31.06 & 30.25 & 29.65 & 30.42 & 35.94 & 32.31 & 32.90 & 28.83 & 25.23 \\
\hline 10 & $\begin{array}{l}\text { SMK NU } \\
\text { Gresik }\end{array}$ & 31.40 & 30.76 & 31.76 & 32.04 & 32.40 & 30.84 & 34.96 & 33.16 & 32.20 & 29.20 \\
\hline 11 & $\begin{array}{l}\text { SMK } \\
\text { Dharmawani } \\
\text { ta }\end{array}$ & 27.50 & 22.94 & 25.70 & 30.65 & 32.30 & 35.89 & 32.06 & 33.89 & 33.69 & 32.89 \\
\hline 12 & $\begin{array}{l}\text { SMK } \\
\text { Taruna Jaya }\end{array}$ & 29.44 & 30.67 & 31.64 & 30.08 & 31.64 & 28.91 & 33.67 & 32.80 & 27.79 & 25.96 \\
\hline & Total & 338.97 & 322.28 & 329.62 & 338.43 & 341.42 & 362.79 & 370.00 & 359.16 & 334.27 & 306.24 \\
\hline \multicolumn{2}{|c|}{ Total Rata-rata } & 28.25 & 29.41 & 30.11 & 30.71 & 31.09 & 32.64 & 33.64 & 32.66 & 30.17 & 27.68 \\
\hline
\end{tabular}

Tabel 6 tersebut di atas menunjukkkan bahwa selama 10 tahun, setiap SMK memiliki output pendidikan yang fluktuatif, grafik tersebut juga menunjukkan bahwa SMK As-Sa'adah adalah salah satu SMK yang memiliki ouput pendidikan tertinggi di kabupaten Gresik selama 3 tahun kebelakang, meskipun pada beberapa tahun sebelumnya SMK ini pernah memiliki output pendidikan yang tergolong rendah, akan tetapi sekolah berbasis pesantren ini terus meningkatkan output pendidikannya pada tahun-tahun selanjutnya. Secara keseluruhan dari biaya operasional pendidikan, output pendidikan dan produktivitas kerja guru mulai tahun pelajaran 2004-2005 s/d 2013-2014 dapat dilihat pada grafik di bawah ini : 


\section{Grafik 1. Perkembangan biaya operasional pendidikan, produktivitas kerja guru dan output pendidikan SMK se-Kabupaten Gresik}

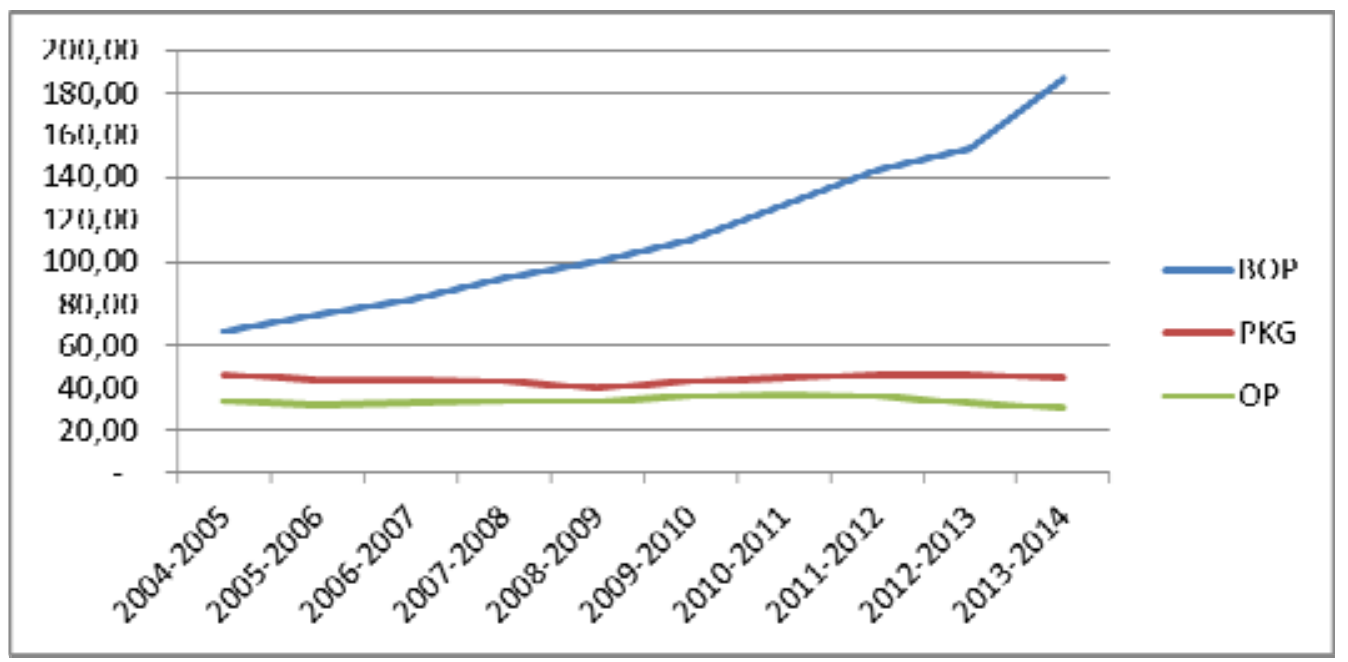

Grafik tersebut di atas menunjukkan bahwa perkembangan biaya operasional pendidikan, bergerak lebih cepat dari variabel yang lain sehingga tidak dapat berjalan beriringan dengan variabel output pendidikan.

Pengujian hipotesis pada penelitian ini dengan pengujian hipotesis model moderasi, hal tersebut dilakukan untuk menentukan kelayakan suatu model regresi. Adapun hasil pengolahan data seperti pada tabel di bawah ini :

Tabel 8. Uji Model Moderasi

\begin{tabular}{|c|c|c|c|c|c|c|c|}
\hline \multirow{2}{*}{ Model } & \multicolumn{2}{|c|}{$\begin{array}{l}\text { Unstandardized } \\
\text { Coefficients }\end{array}$} & \multirow{2}{*}{$\begin{array}{c}\text { Standardized } \\
\text { Coefficients }\end{array}$} & \multirow{2}{*}{$\mathbf{t}$} & \multirow{2}{*}{ Sig. } & \multicolumn{2}{|c|}{$\begin{array}{c}\text { Collinearity } \\
\text { Statistics }\end{array}$} \\
\hline & B & Std. Error & & & & $\begin{array}{c}\text { Tolera } \\
\text { nce }\end{array}$ & VIF \\
\hline (Constant) & 28,651 & 1,062 & & 26,979 & , 000 & & \\
\hline $\begin{array}{l}\text { Biaya } \\
\text { Operasional } \\
\text { Pendidikan }\end{array}$ & $1,630 \mathrm{E}-009$ & .000 & ,431 & 1,898 & , 060 & , 160 & 6,234 \\
\hline $\begin{array}{l}\text { Moderasi } \\
\text { Produktivita } \\
\text { s Kerja } \\
\text { Guru }\end{array}$ & $-2,866 \mathrm{E}-010$ & , 000 &,- 443 & $-1,526$ & , 130 & , 098 & 10,173 \\
\hline
\end{tabular}

Berdasarkan uji statistik $\mathrm{t}$ dengan tingkat kesalahan 5\%, maka kriteria pengujian yang digunakan adalah apabila thitung $>t_{\text {tabel }}$ maka Ha diterima. Dan apabila thitung $\leq t_{\text {tabel }}$ maka Ha ditolak dengan nilai signifikansi $\leq 0.05$. Hasil uji $\mathrm{t}$ tersebut di atas menunjukkan bahwa thitung variabel biaya operasional pendidikan tidak berpengaruh terhadap output pendidikan sebesar 1,898 sedangkan tabel pada tingkat kesalahan 5\% adalah 2,262 $(1,898<2,262)$ atau

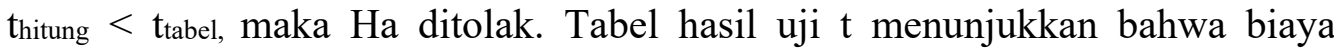
operasional pendidikan tidak berpengaruh terhadap output pendidikan dengan nilai signifikansi sebesar 0,60 atau nilai signifikansinya $\geq 0,05$. Hal ini 
bermakna bahwa, meningkatrnya biaya operasional pendidikan yang dikeluarkan oleh sekolah tidak mengakibatkan output pendidikan dalam hal ini nilai NEM siswa yang semakin meningkat pula. Sebaliknya sekolah yang mengeluarkan biaya operasional pendidikan yang kecil tidak mengakibatkan output pendidikan yang kecil/ rendah pula.

Penelitian ini sejalan dengan yang diungkapkan oleh Elberts dkk. (1999) di Amerika Serikat yang menyatakan bahwa membayar jasa dalam hal ini adalah termasuk dari biaya operasional pendidikan, tidak berpengaruh terhadap indeks prestasi rata-rata (output pendidikan), berkurangnya presentase siswa yang putus sekolah, berkurangnya rata-rata kehadiran setiap hari, meningkatnya presentase siswa yang gagal atau tidak lulus. Siswa yang tidak lulus disini adalah siswa yang memiliki nilai hasil studi yang rendah.

Penelitian lain diungkapkan oleh Flower (1998) di Amerika Serikat. Flower (1998) mengungkapkan bahwa tingginya biaya yang dikeluarkan oleh mahasiswa, tidak berdampak pada kualitas pendidikan yang tinggi pula dari mahasiswa tersebut, kualitas pendidikan disini adalah nilai hasil studi yang diperoleh mahasiswa. Hasil penelitiannya juga mengungkapkan bahwa biaya yang dikeluarkan oleh mahasiswa tidak digunakan secara efektif dan efisien oleh pihak lembaga pendidikan dalam hal peningkatan kompetensi guru/dosen pengajar, dimana guru/pengajar adalah unsur yang terlibat langsung dalam pembelajaran bersama siswa/mahasiswa.

Komisi nasional bidang pendidikan di Amerika Serikat juga mengungkapkan tentang biaya pendidikan yang ditulis oleh Fitzpatrick (2006), bahwa perguruan tinggi bidang akademi keperawatan di Amerika Serikat telah melakukan perombakan sistem pendidikan yaitu dengan menurunkan biaya pendidikan, dikarenakan selama ini biaya pendidikan mahasiswa di akademi tersebut sangat tinggi, akan tetapi tidak memberikan dampak terhadap meningkatnya kualitas (output) dari pendidikan itu sendiri.

Berbeda dengan penelitian yang diungkapkan oleh Fattah (1999), hasil peneltian tersebut menjelaskan bahwa pembiayaan pendidikan memberikan kontribusi yang signifikan terhadap peningkatan mutu (output) pendidikan SD di kabupaten Bandung. Meskipun demikian ada beberapa hal yang kemungkinan dapat menyebabkan tidak berpengaruhnya biaya operasional pendidikan terhadap output pendidikan.

Biaya operasional pendidikan dalam penelitian ini tidak berpengaruh terhadap output pendidikan, hipotesis yang menyatakan ada pengaruh biaya operasional pendidikan terhadap output pendidikan tidak dapat diterima dengan nilai signifikansi sebesar 0,141 atau nilai signifikansi $\geq 0.05$. Hal tersebut disebabkan antara lain karena tidak semua indikator biaya operasional pendidikan digunakan secara langsung atau terkait langsung dalam rangka peningkatan output pendidikan (peningkatan nilai NEM siswa). Biaya-biaya tersebut antara lain; biaya daya listrik, biaya jasa, biaya transportasi, biaya konsumsi, biaya pajak dan biaya asuransi.

Tabel 8 di atas juga menunjukkan bahwa variabel moderator terbukti tidak signifikan dalam mempengaruhi biaya operasional pendidikan terhadap output pendidikan. Dengan nilai koefisien dari variabel moderator yang negatif $(-1,526)$, maka produktivitas kerja guru memberi efek mengurangi pengaruh biaya operasional pendidikan terhadap output pendidikan. Variabel 
produktivitas kerja guru juga menunjukkan nilai yang tidak signifikan $(0,130>$ $0,05)$, maka dapat disimpulkan bahwa produktivitas kerja guru merupakan variabel yang kurang dapat digunakan sebagai variabel moderator dari pengaruh biaya operasional pendidikan terhadap output pendidikan.

Hasil penelitian ini sejalan dengan penelitian yang diungkapkan oleh Alghrim (2010), hasil penelitian menunjukkan bahwa ada hubungan yang negatif atau tidak berpengaruh antara status sosial, populasi siswa dan produktivitas kerja guru terhadap hasil belajar siswa dalam hali ini yaitu output siswa. Meskipun dalam penelitian Miller (2008) diungkapkan bahwa produktivitas guru berpengaruh terhadap kualitas hasil belajar siswa, dimana produktivitas guru dilihat dari tingkat kehadirannya di sekolah.

Kehadiran guru di sekolah tidak menjamin guru tersebut berkomunikasi langsung atau berinteraksi langsung dengan siswa. bekerjasama untuk saling mengeluarkan ide dan gagasan yang dimiliki oleh keduanya. Jumlah guru yang banyak juga tidak menjamin dapat meningkatkan kualitas pendidikan (output pendidikan), jika kuantitas tersebut tidak diimbangi dengan kualitas yang bagus pula. Seperti halnya yang diungkapkan oleh Alghrim (2010) bahwa produktivitas kerja guru di Indian mengalami kenaikan setelah diberlakukan undang-undang akuntabilitas guru. Sehingga kompetensi guru juga penting untuk ditingkatkan sesuai dengan bidang ajar masing-masing guru tersebut.

Produktivitas kerja guru yang tidak memiliki pengaruh terhadap output pendidikan dalam penelitian ini antara lain dimungkinkan karena tidak semua guru terlibat langsung dalam proses peningkatan nilai ujian nasional (NEM) sebagai indikator dari output pendidikan. Sedangkan dalam ujian nasional hanya terdapat 3 bidang mata pelajaran dan 1 kompetensi yang diujikan. Selain itu jumlah guru yang banyak tidak akan menghasilkan output yang baik, jika tidak diimbangi dengan kualitas guru yang baik pula berdasarkan kompetensinya. Setiap guru pada dasarnya memiliki peran yang penting dalam proses peningkatan nilai ujian nasional (NEM) sesuai dengan kompetensi masing-masing, sehingga tidak hanya guru pengajar mata pelajaran ujian nasional saja yang bertanggung jawab terhadap peningkatan nilai ujian nasional (NEM) sebagai output pendidikan sekolah/SMK.

Penelitian berbeda dilakukan oleh Supriadi (2004) yang menyatakan bahwa "biaya pendidikan merupakan salah satu komponen masukan instrumental yang sangat penting dalam penyelenggaraan pendidikan (di sekolah)". Oleh karena itu biaya pendidikan harus dapat digunakan secara efektif dan efisien untuk dapat menghasilkan output pendidikan atau kualitas pendidikan yang tinggi. Jika biaya operasional pendidikan tidak memberikan pengaruh terhadap output pendidikan, dan produktivitas kerja guru juga tidak dapat memberikan pengaruh terhadap output pendidikan, maka biaya operasional pendidikan tidak berpengaruh terhadap output pendidikan melalui produktivitas kerja guru.

Analisis tersebut diatas sejalan dengan yang diungkapkan oleh Flower (1998), biaya pendidikan dapat memberikan pengaruh terhadap output pendidikan atau kualits pendidikan, setelah biaya pendidikan tersebut difokuskan pada peningkatan kompetensi dan kualifikasi dari guru pengajar/dosen di Amerika Serikat. Sehingga produktivitas kerja guru tidak hanya dilihat dari kuantitas guru terhadap jumlah lulusan. Alghrim (2010) juga 
mengungkapkan dalam tulisannya bahwa biaya pendidikan menjadi issue utama dalam meningkatkan prestasi siswa (output), dan menjadikan produktivitas sebagai sesuatu yang penting untuk menghubungkan antara biaya pendidikan dengan prestasi siswa (output siswa).

Hasil penelitian ini menjelaskan bahwa, produktivitas kerja guru kurang dapat dijadikan sebagai moderasi berpengaruhnya biaya operasional pendidikan terhadap output pendidikan (moderasinya rendah). Hal tersebut disebabkan karena tidak semua guru terlibat dalam proses peningkatan nilai ujian nasional siswa (NEM) sebagai output pendidikan sekolah/SMK, begitu pula dengan biaya gaji pokok/tunjangan hanya dikeluarkan untuk sejumlah guru yang ada tanpa ada anggaran khusus untuk biaya peningkatan kompetensi guru. Intinya keberadaan guru untuk menghasilkan lulusan yang berkualitas tidak hanya dilihat kuantitasnya saja, akan tetapi perlu ada peningkatan kompetensi dari guru tersebut yang menjadi tanggung jawab sekolah, sehingga memerlukan anggaran yang khuss untuk mewujudkan hal tersebut, dengan demikian akan berdampak pada peningkatan output pendidikan. Akan tetapi beberapa sekolah yang memiliki output pendidikan yang tinggi, adakalanya sekolah tersebut memiliki sistem boarding school untuk siwanya, sehingga pengayaan mata pelajaran dapat dilakukan secara maksimal, selain itu unsur loyalitas guru terhadap keluarga pesantren cukup bagus.

\section{SIMPULAN}

Biaya operasional pendidikan tidak berpengaruh terhadap output pendidikan. Artinya biaya operasional pendidikan yang meningkat tidak mengakibatkan peningkatan output pendidikan di SMK se-kabupaten Gresik. Demikian sebaliknya biaya operasional yang rendah tidak mengakibatkan penurunan output pendidikan di SMK se-kabupaten Gresik. Rata-rata biaya operasional pendidikan sebesar Rp. 9.477.878.262,-, dan masuk pada kategori kedua (rendah). Sedangkan output pendidikan termasuk pada kategori kedua atau kategori tertinggi.

Biaya Operasional pendidikan tidak berpengaruh terhadap output pendidikan dengan produktivitas kerja guru sebagai variabel moderasi, artinya variabel produktivitas kerja guru merupakan variabel yang kurang dapat digunakan sebagai variabel moderator dari biaya operasional pendidikan dalam mempengaruhi output pendidikan. Sehingga secara tidak langsung biaya operasional pendidikan dengan produktivitas kerja guru sebagai variabel moderasi tidak memiliki pengaruh terhadap output pendidikan. Adapun ratarata produktivitas kerja guru sebesar 4,04 dan termasuk pada kategori kedua (rendah).

\section{DAFTAR RUJUKAN}

Ahlgrim, W Richard. 2010. A Through and Efficient Education: School Funding, Student Achivement and Productuvity. (Unpublished doctoral dissertation). Indiana State University. Terre Haute, Indiana

Arikunto, S. 2006. Prosedur Penelitian Suatu Pendekatan Praktek. Jakarta. Rineka Cipta 
Ekasari, Kurmiati, Yuliana. 2013. Pengaruh Pendidikan dan Kinerja Guru Terhadap Prestasi Belajar Siswa, Universitas Pendidikan Indonesia. Bandung: Repository.upy.edu. perpustakaan.upy.edu

Elberts, Randall. at. al. Teacher Performance incentives and Student Outcomes. National Academy of Sciences Conference entitled "Devising Incentives to Promote Human Capital," held December 17-18, 1999, in Irvine, California.

Fattah, Nanang. 1999. Analisis Hubungan Pembiayaan Pendidikan Sekolah Dasar dengan Mutu Proses dan Hasil Belajar. Mimbar Pendidikan. FIP IKIP Bandung. No. 3/XVIII/1999.

Fare, R S, Grosskopf. F R, Forsund. K, Hayes. A, Hesmati. 2006. Measurement of Productivity and Quality in non-Marketable Services: With application to schools. Quality Assurance in Education. 14.1 (2006): 21-36

Fitzpatrick, Joyce J. 2006. The Cost and Quality Agenda Comes to Higher Education. Nursing Education Perspectives; Nov/Dec 2006; 27, 6; ProQuest Education Journals. Pg 297.

Flower, Ruth. 1998. Cost and quality of higher education The Education Digest; Oct 1998; 64, 2; ProQuest Education Journals pg. 23

Jackson, Kirabo, C,. 2010. Match Quality, Worker Productivity, and Worker Mobility : Direct Evidance From Teacher. National Bureau of Economic Research. 1050 Massachusetts Avenue. Cambridge, MA 02138

Mallet, Susanne; Wren, Steve; Dawes, Mark; Blinco, Amy; Haines, Brett; et al. 2009. Optimising Teacher Input - Maximising Output. Mathematics Teaching. (Nov 2009): 38-40.

Miller, Raegen T; Murnane, Richard J; Willett, John B. 2008. Do worker absences affect productivity? The case of teachers. International Labour Review; 2008; 147, 1; ProQuest Education Journals. pg. 71

Sanjiwani, Estri, Ayu, Ida. 2012. Analisis Biaya Pendiidkan dan Dampaknya Terhadap Kualitas Proses Pembelajaran dan Aspirasi Pendidikan Siswa (Studi Tentang Persepsi Para Siswa SMA Dwijendra Denpasar Tapel 2011/2012) (Tesis tidak dipublikasikan). Universitas Pendidikan Ganesha, Singaraja. http://pasca.undiksha.ac.id/e-journal/index.php/ jurnal_ap/article/ viewFile/459/251

Sugiyono. 2008. Metode Penelitian Kuantitatif Kualitatif dan R\&D. Bandung: Alfabeta

Sukmadinata, Nana Syaodih. 2012. Metode Penelitian Pendidikan. Bandung: Remaja Rosda karya.

Sutikno, Atmadji, Tri. 2009. Indikator Produktivitas Kerja Guru Sekolah Menengah Kejuruan. Teknologi dan Kejuruan, Vol. 32, NO. 1, Februari 2009 : 107-118. 
Supriadi, Dedi. 2004. Satuan Biaya Pendidikan (Dasar dan Menengah). Bandung: Rosda.

Syamsudin. 2009. Pengaruh Biaya Pendidikan Terhadap Mutu hasil Belajar Melalui Mutu Proses Belajar Mengajar Pada Sekolah Menengah Pertama Di Kabupaten Asahan. (Tesis Magister Pendidikan e-library). Universitas Sumatera Utara Medan. Medan

Undang-undang Republik Indonesia Nomor 20 tahun 2003 tentang Sistem Pendidikan Nasional. Jakarta: CV Ekajaya. 